\title{
Obesity Grouping For Single Pregnancy Case Study (Posyandu Puyoh Village)
}

\author{
Evanita $^{1}$ \\ \{evanita@umk.ac.id $\left.{ }^{1}\right\}$ \\ Informatics Engineering of Universitas Muria Kudus, Jl.Gondangmanis PO. BOX 53, Bae, Kudus, \\ Central Java, Indonesia ${ }^{1}$
}

\begin{abstract}
Obesity sometimes experienced by most pregnant women who always try to meet the nutritional needs for the fetus unconsciously. Large appetite during pregnancy leads to increased weight of pregnant women. Increased weight gain during pregnancy affects the mother and prospective baby to be born. In this study, obesity grouping for pregnant women in single pregnancy using Fuzzy Cluster Means (FCM). Grouping is based on Body Mass Index (BMI) with sample of 20 pregnant women. BMI data of pregnant women in the form of height, weight, upper arm circle and stomach range. The data are grouped into 4 clusters: fat, obesity I, obesity II, and obesity III. It resulted smaller positive objective values until the 25 th iteration. It suggests that the grouping results are excellent and deserve as a reference for grouping the types of obesity in a single pregnancy.
\end{abstract}

Keywords: pregnant women, obesity, fuzzy cluster means.

\section{Introduction}

The association between maternal obesity (body mass index $[\mathrm{BMI}] \geq 30$ ) and the risk of a neural tube defect affected pregnancy (NTD). We also studied relationships between perinatal folate intake from food and the NTD risk by maternal BMI. A majority of case mothers (77\%) and controls $(86 \%)$ were interviewed within 6 months after delivery or pregnancy termination. Logistic regression models were used to examine the association between maternal obesity and the NTD risk after adjusting for maternal race, age, education, smoking, alcohol/drug use, chronic conditions, and multivitamin use within six periconceptional months. Stratified analysis by maternal BMI ( $\geq 25$ vs. $<25$ ) was conducted for the association between food folate and the NTD risk. After adjustment for confounders, obese women (BMI $\geq 30$ ) had twice higher odds of having an NTD-affected pregnancy (odds ratios $[\mathrm{OR}]=2.06,95 \%$ confidence interval $[\mathrm{CI}]=1.12,3.81$ ) than normal weight women (BMI: 18.0-24.9). Compared to the lowest quartile of average daily folate intake from food, the upper three quartiles had lower odds of NTDs in offspring. The NTD-protective association was stronger in overweight/obese women $(\mathrm{BMI} \geq 25)$ than in normal/underweight women $(\mathrm{BMI}<25)[1]$.

Having offspring is something which every family desires. In obtaining offspring, of course, many processes that must be done. One of them is the mother's pregnancy. In the process of pregnancy which takes about 9 months, many things will be done by the mother to take care for the fetus to be born in good health. Eating nutritious foods and drinking special milk for pregnant women are routine activities every day. Increasing weight body due to the

ICCSET 2018, October 25-26, Kudus, Indonesia

Copyright (C) 2018 EAI

DOI 10.4108/eai.24-10-2018.2280593 
growing fetus and large enough of appetite during pregnancy can trigger the presence of obesity among pregnant women unconsciously.

Obesity or overweight is a scourge of its own for most women, including the mothers of postpartum. Most of them ignores the warning about obesity during pregnancy. The danger of obesity effects for their health and also the prospective baby to be born. The dangers of obesity for the mother such as heart disease, shortness of breath, diabetes, preeclampsia to miscarriage can be experienced by pregnant women who suffer from high levels of obesity. As for the baby who will be born later, they are susceptible to obesity and diabetes which are derived from the mother during pregnancy such as disability of the spine, brain defects, until the disruption of the lungs. For the reasons above, obesity needs to be watched by pregnant women not only by controlling of diet diligently but also exercise sufficiently. This study attempts to group the pregnant women in single pregnancy into levels of body mass and ranging them from fat to 3 levels of obesity. Data obtained from a survey of 20 pregnant women in Posyandu Puyoh village. Grouping the pregnant women used Fuzzy Cluster Means (FCM) method with 4 clusters according to body mass size. From the results of this grouping are expected to provide knowledge about the level of weight of pregnant women in order to be aware for the dangers of obesity which will occur during pregnancy.

Previous studies have classified data using the K-Means clustering method by grouping $\mathrm{n}$ objects into class $\mathrm{k}$ based on their distance to class center. Grouping the existing data based on nutritional status, size of the skeleton and physical condition parameters from some university students. Anyone who knows the value of Body Mass Index (BMI), the person can control the weight so that he or she can achieve a normal weight to height. Meanwhile, anyone who knows the size of the skeleton then the person can control his or her weight in order to always be in the ideal state. From the result of the research on 20 sample data, there were 3 groups of university students based on BMI value and skeleton size, namely: normal BMI and large skeleton, medium obesity BMI and medium skeleton, heavy obesity BMI and small skeleton [2].

The grouping of under five children's nutritional status was cross tabulated with children's nutritional status based on WHO-2005 by K-Means method and K-Means Bootstrap method at Ajung Public Health Center, Jember using secondary data without direct interaction with the subjects of the research. The study concluded that the total accuracy (TAR) and Total Error Rate (TER) determined the nutritional status. K-Means method were TAR $=0.9$ and, TER = 0.1 and Bootstrap K-Means method $(B=25)$ TAR $=0.925$ and TER $=0.075$; after it was cross tabulated with nutritional status based on WHO -2005 (weight for age). In general the best method is Bootstrap K-Means ( $\mathrm{B}=75)$. The K-Means Bootstrap method can be used as an alternative way to determine the children's nutritional status [3].

\section{Research Method}

\subsection{Single Pregnancy}

Single pregnancy is the number of fetuses in a single. This pregnancy begins with the conception of one ovum by one sperm cell alone [4]. A single pregnancy, the estimated weight of the fetus at 20 weeks gestation is 500 grams, whereas at 28 weeks is $1 \mathrm{~kg}$. After 28 weeks of gestation, the increase in fetal weight is about 200 grams per week (of course it depends on the size of the pregnant woman's body), so that at 38 weeks of gestation the estimated fetal 
weight is $3-3.6 \mathrm{~kg}$ (estimated fetal weight of $2.5 \mathrm{~kg}$ is used as a lower limit for the age of 38 weeks, although in pregnant women who are underweight or with a small body size can be less than $2.5 \mathrm{~kg}$ ). Placental weight usually is not measured during pregnancy because it is difficult, but it can be estimated based on the ratio of volume of the fetus on USG. The weight of the placenta is usually one-sixth of the weight of the fetus or about $0.7 \mathrm{~kg}$ (after the baby was born). Not only the weight of the fetus and placenta are estimated to increase the weight of women but also comes from the breast $1 \mathrm{~kg}, 1 \mathrm{~kg}$ uterus, $1.4-1.8 \mathrm{~kg}$ blood volume, Increased fluid volume of 1.4 to $1.8 \mathrm{~kg}$ and $2.7-3.6 \mathrm{~kg}$ fat reserves [5].

\subsection{Obesity}

Obesity is an excessive or abnormal buildup of fat that can interfere with health [6]. Obesity is considered as one of the factors which can increase the prevalence of hypertension, glucose intolerance, and atherosclerotic coronary heart in obese patients [7].

\subsection{Body Mass Index (BMI)}

Body Mass Index (BMI) is a measure which compares weight and height. BMI is a technique to calculate the weight index, so we can know the category of our classified body as thin, normal, or fat. BMI can be used to control weight and to achieve a normal weight to height [2]. In calculating BMI, it required two parameters, namely weight (kg) and height (m). BMI can be calculated using the formula [2]:

$$
B M I=\frac{W(k g)}{H^{2}(m)}
$$

$$
\begin{array}{lll}
\text { Code: } & & \\
\text { BMI } & = & \text { Body Mass Index } \\
\mathrm{W} & = & \text { Weight in kilogram } \\
\mathrm{H} & = & \text { Height in meter }
\end{array}
$$

Table 1. BMI Category.

\begin{tabular}{ll}
\hline BMI $\left(\mathrm{kg} / \mathrm{m}^{\wedge} 2\right)$ & Category \\
\hline$<18,5$ & Less \\
$18,5-24,9$ & Ideal \\
$25-29,9$ & Fat \\
$30-34,9$ & Obesity I \\
$35-39,9$ & Obesity II \\
$\geq 40$ & Obesity III \\
\hline
\end{tabular}

BMI below 18.5 indicates underweight. The ideal weight during pregnancy is 12 to $18 \mathrm{~kg}$. BMI between 18,5 to 24,9 is ideal, a good weight gain is 11 to $16 \mathrm{~kg}$. In the first trimester, the weight gain of pregnant women should be 0,5 to $2,5 \mathrm{~kg}$, followed by weight gain of $0,5 \mathrm{~kg}$ every week. BMI between 25 to 29,9 indicates overweight. The weight gain of pregnant women is expected not too much, ideally 7 to $11 \mathrm{~kg}$. BMI above 30 indicates obesity or overweight. The ideal weight gain is 5 to $9 \mathrm{~kg}$ only. For example, if a mother weight is $50 \mathrm{~kg}$ 
with a height of 1,6 meters, then her BMI is $50 /(1,6 \times 1,6)=19,5$, then the total ideal weight gain of this pregnant woman is 11 to $16 \mathrm{~kg}$.

\subsection{Fuzzy Clustering Mean (FCM)}

Fuzzy Clustering Mean (FCM) is grouping data into certain clusters based on membership values. The cluster center is determined on the initial conditions which mark the average location of each cluster. Repairing the cluster center and membership value of each data repeatedly will show that the cluster center is moving to the right location. The loop is based on the minimization of objective function [8][9]. Figure 1 is flowchart FCM process:

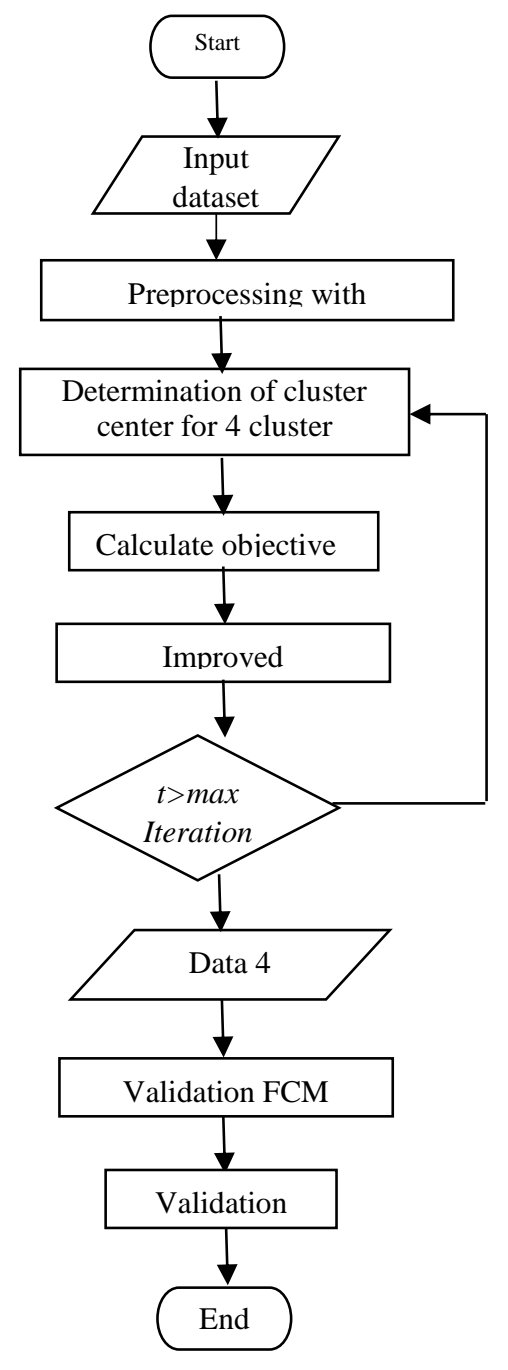

Fig. 1. FCM Process.

The sequence of FCM algorithm process steps is as follows [10][11]: 
1. Prepare the data forming a matrix of size $n \times m$, which means $n$ is the amount of data to be in the cluster and $m$ is the number of variable.

2. Determine the number of cluster to be formed $\mathrm{C}(\geq 2)$

3. Determine the weight $\mathrm{w}(>1)$

4. Maximum iteration

5. Criteria of termination $\xi$ (very small positive value )

6. Initial iteration $\mathrm{t}=1, \Delta=1$

7. Calculate the cluster center, $\mathrm{V}$ for each cluster :

$$
V_{k j}=\frac{\sum_{i=1}^{n}\left(\mu_{i k}\right)^{w} \cdot X_{i j}}{\sum_{i=1}^{n}\left(\mu_{i k}\right)^{w}}
$$

Code:

$\mu=$ Membership value

$\mathrm{X}=$ Matrix data

8. Calculation of objective function :

$$
P_{t}=\sum_{i=1}^{n} \sum_{k=1}^{c}\left(\left[\sum_{j=1}^{m}\left(X_{i j}-V_{k j}\right)^{2}\right]\left(\mu_{i k}\right)^{w}\right)
$$

Code:

$P_{t}=$ Objective function

$\mathrm{V}=$ Center of the cluster

9. Improvement of membership degree:

$$
\mu_{i k}=\frac{\left[\sum_{j=1}^{m}\left(X_{i j}-V_{k j}\right)^{2}\right]^{\frac{-1}{w-1}}}{\sum_{k=1}^{c}\left[\sum_{j=1}^{m}\left(X_{i j}-V_{k j}\right)^{2}\right]^{\frac{-1}{w-1}}}
$$

Code:

$\mathrm{X}=$ Matrix data

$w=$ Weight 
10. Criteria for dismissal of the process

$\left(\left|P_{t}-P_{t-1}\right|<\xi\right)$ or $(t>\max$ Iterasi $)$ then the process stopped or completed, where if not $t=t+1$, repeat from step 7 .

\section{Results and Analysis}

Grouping obesity types in pregnant women by FCM method is done to 20 pregnant women at age pregnancy of 28 to 36 weeks. The type of variables used is multivariate or more than one variable. There are 4 variables that are very influential on the classification of the type of obesity in pregnant women, namely, weight in kilograms, height in centimeters, upper arm circle in centimeters, and stomach range in centimeters. Table 2 is the sample data from the observation.

Table 2. Sample Data.

\begin{tabular}{cccccc}
\hline No. & $\begin{array}{c}\text { Gestational Age } \\
(\text { week })\end{array}$ & $\begin{array}{c}\text { Weight } \\
(\mathrm{kg})\end{array}$ & $\begin{array}{c}\text { Height } \\
(\mathrm{cm})\end{array}$ & $\begin{array}{c}\text { Upper Arm } \\
\text { Circumference }(\mathrm{cm})\end{array}$ & $\begin{array}{c}\text { Abdominal } \\
\text { Circumference }(\mathrm{cm})\end{array}$ \\
\hline 1 & 30 & 50 & 145 & 30 & 100 \\
2 & 32 & 68 & 163 & 35 & 120 \\
3 & 36 & 56 & 155 & 30 & 100 \\
4 & 36 & 45 & 154 & 25 & 90 \\
5 & 35 & 80 & 160 & 35 & 125 \\
6 & 28 & 62 & 158 & 30 & 100 \\
7 & 32 & 65 & 160 & 32 & 100 \\
8 & 35 & 73 & 165 & 33 & 100 \\
9 & 30 & 67 & 156 & 33 & 110 \\
10 & 36 & 80 & 165 & 35 & 115 \\
11 & 36 & 85 & 165 & 35 & 100 \\
12 & 28 & 45 & 150 & 25 & 110 \\
13 & 30 & 67 & 156 & 30 & 110 \\
14 & 32 & 75 & 160 & 30 & 95 \\
15 & 29 & 77 & 150 & 35 & 90 \\
16 & 28 & 53 & 158 & 27 & 98 \\
17 & 30 & 48 & 158 & 25 & 95 \\
18 & 33 & 70 & 160 & 30 & 95 \\
19 & 30 & 57 & 155 & 28 & \\
20 & 34 & 50 & 154 & 30 & \\
\hline
\end{tabular}

Multivariate data be normalized so that the output results obtained more accurate. Normalization equations used [9]:

$$
\mathrm{X} \text { normalization }=\frac{(x-x \min )}{(x \max -x \min )}
$$


Table 3. Data Normalization Results.

\begin{tabular}{lllll}
\hline No. & \multicolumn{1}{r}{ Weight } & Height & \multicolumn{1}{c}{$\begin{array}{c}\text { Upper Arm } \\
\text { Circumference }\end{array}$} & $\begin{array}{c}\text { Abdominal } \\
\text { Circumference }\end{array}$ \\
\hline 1 & 0,125 & 0 & 0,5 & 0,285714 \\
2 & 0,575 & 0,9 & 1 & 0,857143 \\
3 & 0,275 & 0,5 & 0,5 & 0,285714 \\
4 & 0 & 0,45 & 0 & 0 \\
5 & 0,875 & 0,75 & 1 & 1 \\
6 & 0,425 & 0,65 & 0,5 & 0,285714 \\
7 & 0,5 & 0,75 & 0,7 & 0,285714 \\
8 & 0,7 & 1 & 0,8 & 0,285714 \\
9 & 0,55 & 0,55 & 0,8 & 0,285714 \\
$\ldots$ & $\ldots$ & $\ldots$ & $\ldots$ & $\ldots$ \\
20 & 0,125 & 0,45 & 0,5 & 0,142857 \\
\hline
\end{tabular}

Normalized data being calculated into the clustering process using the Fuzzy Clustering Mean (FCM) method with the help of Mathlab. The first FCM process is to determine the number of clusters which be produced first, then, to determine the center of the initial centroid cluster in a random way or by paying attention to the maximum and minimum value of the entire sample data. The data being clustered into 4 groups: fat, obesity I, obesity II and obesity III. Center cluster with $4 \times 4$ matrixes consisting of 4 rows and 4 columns obtained from sample data after normalized is as follows:

$$
\left[\begin{array}{llll}
0,0514 & 0,4643 & 0,0421 & 0,0605 \\
0,2545 & 0,4588 & 0,4569 & 0,2235 \\
0,5754 & 0,6818 & 0,6350 & 0,3157 \\
0,8364 & 0,8868 & 0,9840 & 0,7511
\end{array}\right]
$$

Cluster center is used for calculation of the objective function from first iteration to the stop process condition in which there is a process of improvement in membership degree. From the calculation results in Mathlab, the data clustering stops at 25th iteration with each value of the objective function as shown in figure 2 . 


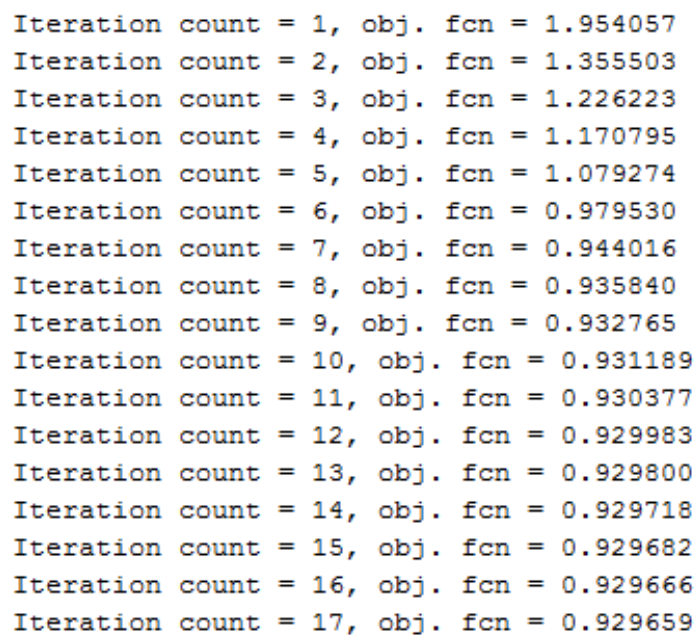

Fig. 2. The Value of the Objective Functions.

The positive objective function value decreasing from iteration 1 to iteration 25 on the stop condition indicates that the result of grouping the sample data is very good.

\section{The Results}

From 20 sample data of pregnant women grouped into 4 clusters: cluster 1 fat pregnant women, cluster 2 obesity level I, cluster 3 obesity level II and cluster 4 obesity level III. The grouping is illustrated in figure 3 .

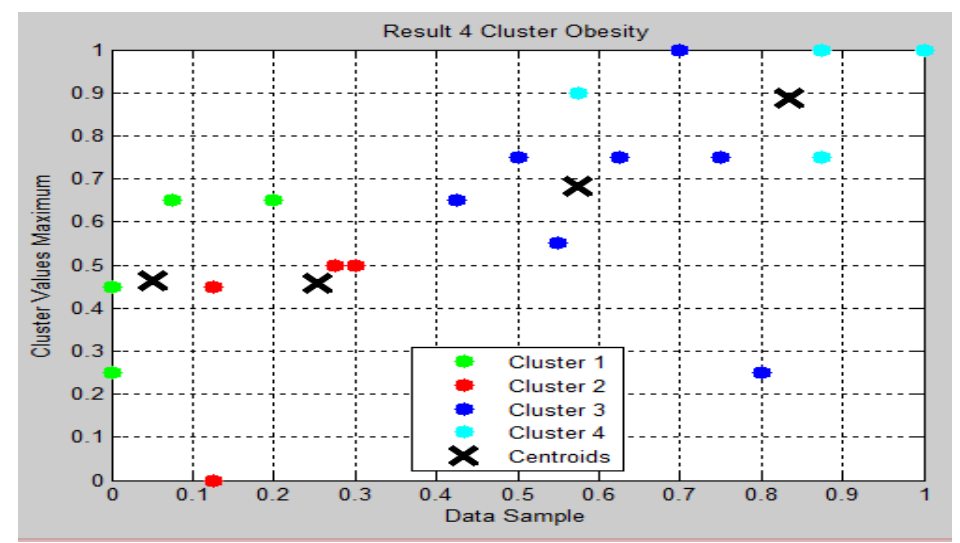

Fig. 3. The Clustering Results.

The green color indicates cluster 1 consisting of 4 members: data 4, 12, 16 and 17. The red color indicates cluster 2 consisting of 4 members: data 1, 3, 19 and 20. The blue color shows cluster 3 consisting of 8 members: data $6,7,8,9,13,14,15$ and 18 . The bluelight color 
shows cluster 4 consisting of 4 members: data 2, 5, 10 and 11. Star $(*)$ is the center of the cluster. The final stage after obtaining the output of the 4 clusters is the calculation. FCM calculation uses MPCI (Modification Pertiotion Coefficient Index). The calculation results are quite good with a value of 0.4662 . Here are the results of grouping data into 4 clusters:

Table 4. Grouping Obesity Level

\begin{tabular}{ccccccl}
\hline No. & $\begin{array}{c}\text { Gestational } \\
\text { Age (week) }\end{array}$ & $\begin{array}{c}\text { Weight } \\
(\mathrm{kg})\end{array}$ & $\begin{array}{c}\text { Height } \\
(\mathrm{cm})\end{array}$ & $\begin{array}{c}\text { Upper Arm } \\
\text { Circumference } \\
(\mathrm{cm})\end{array}$ & $\begin{array}{c}\text { Abdominal } \\
\text { Circumference } \\
(\mathrm{cm})\end{array}$ & $\begin{array}{c}\text { Level } \\
\text { Obesity }\end{array}$ \\
\hline 1 & 30 & 50 & 145 & 30 & 100 & Level I \\
2 & 32 & 68 & 163 & 35 & 120 & Level III \\
3 & 36 & 56 & 155 & 30 & 100 & Level I \\
4 & 36 & 45 & 154 & 25 & 90 & Fat \\
5 & 35 & 80 & 160 & 35 & 125 & Level III \\
6 & 28 & 62 & 158 & 30 & 100 & Level II \\
7 & 32 & 65 & 160 & 32 & 100 & Level II \\
8 & 35 & 73 & 165 & 33 & 100 & Level II \\
9 & 30 & 67 & 156 & 33 & 100 & Level II \\
10 & 36 & 80 & 165 & 35 & 110 & Level III \\
11 & 36 & 85 & 165 & 35 & 115 & Level III \\
12 & 28 & 45 & 150 & 25 & 95 & Fat \\
13 & 30 & 67 & 156 & 30 & 100 & Level II \\
14 & 32 & 75 & 160 & 30 & 110 & Level II \\
15 & 29 & 77 & 150 & 35 & 110 & Level II \\
16 & 28 & 53 & 158 & 27 & 95 & Fat \\
17 & 30 & 48 & 158 & 25 & 90 & Fat \\
18 & 33 & 70 & 160 & 30 & 98 & Level II \\
19 & 30 & 57 & 155 & 28 & 95 & Level I \\
20 & 34 & 50 & 154 & 30 & 95 & Level I \\
\hline
\end{tabular}

At age pregnancy 28 to 36 weeks is expected for fat group, weight gain to give birth about 7-11 kg of weight before pregnancy and for pregnant women with obesity I, obesity II and obesity III, weight gain during pregnancy about $5-9 \mathrm{~kg}$ of weight before pregnancy. As a comparison, in the cluster it is not only using FCM data but also using K-Means clustering. The cluster center and output values of K-Means are as follows [12][13][14].

$$
\left|\begin{array}{llll}
0,0687 & 0,5000 & 0,0500 & 0,0714 \\
0,2063 & 0,3625 & 0,4500 & 0,2143 \\
0,5857 & 0,7143 & 0,6143 & 0,3184 \\
0,8250 & 0,7800 & 1,0000 & 0,7429
\end{array}\right|
$$

From the K-Means output and the cluster center above the performance test is performed with the Silhouette Index method [15][16].

$$
S I_{i}^{j}=\frac{b_{i}^{j}-a_{i}^{j}}{\max \left\{a_{i}^{j}, b_{i}^{j}\right\}}
$$




$$
\begin{aligned}
& S I_{j}=\frac{1}{m} \sum_{i=1}^{m_{j}} S I_{i}^{j} \\
& S I=\frac{1}{k} \sum_{j=1}^{k} S I_{j}
\end{aligned}
$$

The Silhouette Index for K-Means of 0,3088 shows good enough performance. But FCM performance with MPCI shows better results of 0,4662 which is closer to the validation value of 1 . The research is better than previous studies have classified data using the K-Means clustering method by grouping $n$ objects into class $k$ based on their distance to class center. This is a comparison between the FCM and K-Means methods.

\section{Conclusion}

Grouping 4 clusters of obesity in single pregnancy by Fuzzy Cluster Means method resulted smaller positive objective values until the 25th iteration with MPCI performance value of 0.4662 . Pregnant women weight is about $45-53 \mathrm{~kg}$, height $150-154 \mathrm{~cm}$, upper arm circle $25-27 \mathrm{~cm}$ and stomach range of $90-95 \mathrm{~cm}$ at the position of fat ideally, weight gain about $7-11 \mathrm{~kg}$ of weight before pregnant to give birth. These results indicate the classification of the type of obesity is better than K-Means clustering using SI performance of 0.3088 . Pregnant women weight is about $50-57 \mathrm{~kg}$, height $145-155 \mathrm{~cm}$, upper arm circle $28-30 \mathrm{~cm}$ and stomach range $95-100 \mathrm{~cm}$ at the position of obesity level I ideally, weight gain about 5-9 kg of weight before pregnancy to give birth. It is expected that pregnant women can maintain their body mass to avoid obesity which can interfere with maternal and fetal health by taking care to the levels of calories and nutrients of food and doing exercise. This study uses limited data. It is can be further developed by updating data or comparing with other methods for future needs.

\section{References}

[1] D. M. McMahon, J. Liu, H. Zhang, M. E. Torres, and R. G. Best, "Maternal obesity, folate intake, and neural tube defects in offspring," Birth Defects Res. Part A Clin. Mol. Teratol., vol. 97, no. 2, pp. 115-122, Feb. 2013.

[2] T. Rismawan and S. Kusumadewi, "Aplikasi K-Means Untuk Pengelompokkan Mahasiswa Berdasarkan Nilai Body Mass Index (Bmi) \& Ukuran Kerangka,” Semin. Nas. Apl. Teknol. Inf., p. E-43-E-48, 2008.

[3] H. Prasetyo, Kuntoro, Soenarnatalina, M. Adriani, and B. Wijanarko, "Penerapan Clustering Bootstrap dengan Metode K-Means," J. Biometrika dan Kependud., vol. 3, no. 1, pp. 43-49, 2014.

[4] Sulistyawati, Asuhan Kebidanan Pada Masa Kehamilan. Jakarta: Salemba Medika, 2011.

[5] R. Novianti, "Asuhan Kebidanan Komprehensif Kehamilan, Persalinan, Bayi Baru Lahir (BBL), Nifas Dan Keluarga Berencana (KB) Pada Ny. Y G2P1A0 Umur 30 Tahun Umur Kehamilan 38 Minggu 3 Hari Di Puskesmas Ii Tambak," Universitas Muhammadiyah Purwokerto, 2016. 
[6] World Health Organization, "Childhood overweight and obesity," 2011. [Online]. Available: http://www.who.int/dietphysicalactivity/childhood/en/.

[7] Rustika and R. Oemiati, "Coronary Heart Disease [CHD] with Obesity in Kebon Kalapa Village, Bogor [Baseline Cohort Study of Non-communicable Diseases Risk Factors]," Bul. Penelit. Sist. Kesehat., vol. 17, no. 4, pp. 385-393, 2014.

[8] S. Kusumadewi, Neuro-Fuzzy Integrasi Sistem Fuzzy \& Jaringan Syaraf. Yogyakarta: Graha Ilmu, 2010.

[9] E. Noersasongko, F. T. Julfia, A. Syukur, Purwanto, R. A. Pramunendar, and C. Supriyanto, "A Tourism Arrival Forecasting using Genetic Algorithm based Neural Network," Indian J. Sci. Technol., vol. 9, no. 4, 2016.

[10] J. C. Bezdek, R. Ehrlich, and W. Full, "FCM: The fuzzy c-means clustering algorithm," Comput. Geosci., vol. 10, no. 2, pp. 191-203, 1984.

[11] E. Prasetyo, Data Mining Mengolah Data Menjadi Informasi Menggunakan Matlab. Yogyakarta: Andi, 2014.

[12] S. Sivarathri and A. Govardhan, "Experiments on Hypothesis 'Fuzzy K-Means is Better than K-Means For Clustering,"' Internatinal J. Data Min. Knowl. Manag. Process, vol. 4, no. 5, pp. 21-34, 2014.

[13] Z. Cebeci and F. Yildiz, "Comparison of K-Means and Fuzzy C-Means Algorithms on Different Cluster Structures,” J. Agric. Informatics, vol. 6, no. 3, pp. 13-23, 2015.

[14] A. Ramadhan, Z. Efendi, and Mustakim, "Perbandingan K-Means dan Fuzzy C-Means untuk Pengelompokan Data User Knowledge Modeling," Semin. Nas. Teknol. Informasi, Komun. dan Ind. 9, pp. 219-226, 2017.

[15] M. Halkidi, Y. Batistakis, and M. Vazirgiannis, "On clustering validation techniques," J. Intell. Inf. Syst., vol. 17, no. 2-3, pp. 107-145, 2001.

[16] D. F. Iezzi, "a New Method for Adapting the K-Means Algorithm To Text Mining," Ital. J. Appl. Stat., vol. 22, no. 1, pp. 65-76, 2010. 